When the Academy's building was erected in 1924 , it was planned to accommodate additional wings as the need developed and funds became available. With the greatly increased scope of the Academy's work, more space has been urgently needed, and many activities of the Academy-Research Council have had to be housed in widely scattered locations throughout Washington.

The work of the Academy-Research Council is carried on by more than a thousand committees comprising scientists who voluntarily give their time and represent all fields of science; they are served by a full-time staff of more than 1,100. More than $10,000,000$ dollars a year is provided for the work of the Academy by private foundations, contracts and grants from the Federal Government, and income from the Academy endowment of approximately $7,000,000$ dollars a year.

\section{Elections}

Dr. Hugh L. Dryden, deputy administrator of the National Aeronautics and Space Administration, has been elected to a second four-year term as home secretary of the U.S. National Academy of Sciences.

Dr. Roger Adams, research professor of chemistry, University of Illinois, and Dr. William V. Houston, president of Rice Institute, have been elected members of the Council. The two councillors who are retiring are Dr. I. I. Rabi, professor of physics, Columbia University, and Dr. F. E. Terman, professor of electric engineering, Stanford University.

As members of the Council of the Academy, the home secretary and the two new councillors will share responsibility for the general conduct of the Academy and its National Research Council.

The following have been elected to membership of the Academy :

Dr. Philip H. Abelson, director of the Geophysical Laboratory, Department of Terrestrial Magnetism, Carnegie Institution of Washington.

Prof. Walker Bleakney, Brackett research professor in Princeton University.

Prof. David Bonner, professor of microbiology, Yale University.

Prof. Tom Bonner, professor of physics, Rice Institute.

Dr. Walter Brattain, research physicist, Bell Telephone Laboratories (on leave with the National Defense Research Committee, Columbia University).

Prof. Leo Brewer, professor of chemistry, University of California at Berkeley.

Prof. Frank Brink, dean of graduate studies, Rockefeller Institute.
Prof. Jens C. Clausen, Division of Plant Biology, Carnegie Institution of Washington, and professor of biology, Stanford University.

Prof. Samuel Eilenberg, professor of mathematics, Columbia University.

Prof. John D. Ferry, professor of chemistry, University of Wisconsin.

Prof. Kurt O. Friedrichs, professor of applied mathematics, New York University.

Prof. Hiram B. Glass, professor of biology, Johns Hopkins University.

Prof. M. J. Herskovits, professor of anthropology, Northwestern University; former visiting professor, Graduate School, University of Illinois.

Prof. Herman M. Kalckar, professor of biochemistry, Johns Hopkins University.

Prof. Konrad B. Krauskopf, professor of geology, Stanford University, and geologist, U.S. Geological Survey.

Prof. I. Michael Lerner, professor of geneties, University of California at Berkeley.

Dr. Rudolph L. B. Minkowski, Mount Wilson and Palomar Observatories, and research associate, California Institute of Technology.

Dr. Harry F. Olson, Radio Corporation of America Laboratories.

Prof. C. Pfaffmann, professor of psychology, Brown University.

Prof. Richard J. Russell, professor of physical geography, and dean of the Graduate School, Louisiana State University.

Prof. John A. Simpson, scientific consultant, Argonne National Laboratory.

Prof. Dean S. Tarbell, professor of organic chemistry, University of Rochester.

Prof. Henry Taube, professor of chemistry, University of Chicago.

Prof. James A. Van Allen, professor of physics, State University of Iowa.

Prof. Cecil J. Watson, professor of medieine, University of Minnesota.

Prof. Gregor Wentzel, professor of physics, University of Chicago.

Prof. Fred L. Whipple, director, Smithsonian Astrophysical Observatory (a close associate with Harvard College Observatory).

Prof. William B. Wood, jun., vice-president of medical affairs, and professor-elect of microbiology, Johns Hopkins University.

Prof. Clarence M. Zener, director, Westinghouse Research Laboratories.

Dr. Raymond E. Zirkle, professor of radiobiology, University of Chicago.

\title{
CHARACTERISTICS OF THE ANTARCTIC ICE-SHEET
}

WHE Royal Astronomical Society Geophysical
Discussion of February 27 was held jointly, in
the Society's rooms at Burlington House, with the
British Glaciological Society. This combining of in-
terests by the two organizations was matehed by the
bringing together of the theoretical with the directly
practical interests, for the main speakers were Dr.
J. F. Nye (chairman) on one hand, and M. B. Imbert,
Mr. J. G. D. Pratt and Dr. H. Lister on the other.
Dr. Nye's important contributions to the study of ice-sheets are well known and, perhaps more than anyone, he has shown clearly what physical properties should be measured by the expeditions that go to make the necessarily difficult and sometimes hazardous experiments; and he has put together the numbers of the problem so that the field men can plan their experiments and know when they are getting a reasonable answer.

M. Imbert has for many years been principal assistant to Dr. Paul Emile Victor of the Expéditions 
Polaires Françaises, and Mr. Pratt is a seismologist of world-wide experience in the British Petroleum organization. They both had returned recently from Antarctica and were able to describe some of their results, both seismic and gravitational, fresh from the detailed analysis that awaited their return home. As opposed to the static problem of what is there now, Dr. Lister studies the mechanism of deposition of snow and its formation into an ice-sheet, together with the dynamical aspects and the history of these phenomena. Dr. Lister and Mr. Pratt were members of Sir Vivian Fuchs's Commonwealth Trans-Antaretic Expedition, and M. Imbert was leader of the French team in Antarctica for the International Geophysical Year.

Dr. Nye explained that the behaviour of an icesheet is governed by two opposing forces : the weight, which tends to squeeze the ice out sideways, and the resistance to outward flow provided by the bed. These two forces are essentially in balance.

The properties of the ice depend upon the temperature distribution in the ice, and this in turn is affected by two main sources of heat. Heat is flowing from the Earth itself, presumably in the absence of voleanic activity, at the normal rate, and it is also developed by friction as the ice moves over the rock bed. If the effects of transverse convection are ignored, theory suggests that both sources of heat are tending to make the lower layers of ice warmer than the upper ones. The ice will therefore become more plastic at the bottom than at the top. The shear stress tending to move the mass of ice is known to increase linearly with depth in the ice, and therefore the shear distortion will take place predominantly in the lowest layers. It does not matter very much if, in the analysis, the distortion is regarded as slipping on the rock bed rather than very intense shear in the lowest layer.

The movement of the ice-sheet is outwards towards the unconstrained perimeter, and the calculated strain rates at the ice-rock interface are of the order of about $10^{-2}$ per annum. This is much higher than the slow rate (about $10^{-4}$ per annum) of the squeezing down movement of vertical compaction, which is partly or entirely compensated by the addition of new material by snowfall. However, it is the weight of accumulated snow that ultimately provides the driving force for the ice-sheet, and the connexion between the vertical and the outward strains in the ice is such that, in a steady state, the outflow is just sufficient to balance the accumulation.

A simple model of the ice-sheet shows that the steady-state thickness of the ice is proportional only to the fifth or sixth root of the accumulation. This means that the height of the ice-sheet is very insensitive to even long-period changes of accumulation, and it is for this reason that calculations of the equilibrium form of an ice-sheet can be made with fair accuracy without a knowledge of the accumulation. The relevant measurements that are required, therefore, from the field experiments are a knowledge of the topography, the thickness of the ice, and the past and present rates of accumulation.

M. Imbert's results covered a traverse, 300 miles long, running inland from the French International Geophysical Year base in Adelie Land. In the 1957-58 season seventy-five shots were fired to obtain seismic reflexion results at twenty-five stations. The recording gear covered the nominal frequency-range of $600 \mathrm{c.} / \mathrm{s}$. , but as with most Arctic and Antarctic seismic investigations it was found desirable to put the charge as deep as possible into the layers of poorly compacted snow. A charge of $1 \mathrm{kgm}$. of high explosive at a depth of $18 \mathrm{~m}$. was found to give readable reflexions, and the quality of a number of 'typical records' that were shown were certainly excellent. Mr. Pratt managed to bury some of his charges to a depth of $12 \mathrm{~m}$., but this was not really deep enough, and in many cases lack of time forced him to be content with surface shots. It is noticeable that the reflexions do not stand out so clearly as some of M. Imbert's, but care must be taken in ascribing record quality entirely to the effect of depth of charge, since some results from the British North Greenland Expedition show that unexplained phenomena deep down in the ice also have considerable effect on the strength of reflexions.

The French seismic profile was supplemented in 1958-59 by seventy gravity stations, and the topography of the surface of the ice-sheet was measured to an accuracy estimated at $15-20 \mathrm{~m}$. Barometric heights were backed up by estimates of atmospheric pressure obtained from radiosonde measurements. The mean height of bedrock was $40 \mathrm{~m}$. below sealevel along the traverse, but elevations and depressions of several hundred metres were observed about this mean. If $h \mathrm{~km}$. is the height of the surface above sea-level at point $x \mathrm{~km}$. inland, then the surface of the ice fitted the ellipse :

$$
\left(\frac{h}{2 \cdot 68}\right)^{2}+\left(\frac{550-x}{550}\right)^{2}=1
$$

with a root-mean-square error of $\pm 25 \mathrm{~m}$.

The profile presented by Mr. Pratt covered the 2,000-mile course of the Commonwealth TransAntarctic Expedition. The seismic picture was different from that of other observers in that the ice-rock interface was, except for two troughs on the Weddell Sea side of the South Pole, well above (about $1,500 \mathrm{~m}$.) sea-level. This may be accounted for on the Ross Sea side of the pole by the fact that the course of the expedition lay over the foothills of a known mountain range.

The gravity measurements were checked at the South Pole and at the Ross Sea, but the uncertainty about height in between gives a possible error of 25-50 mgal. The estimated error due to drift is much less than this, of the order of 5 mgal. The gravity results support the seismic picture, and Bouguer anomalies have been drawn assuming the profile found from the seismic measurements, together with a rock density of $2 \cdot 1 \mathrm{gm} . / \mathrm{cm} .^{3}$. There is a large anomaly of $-200 \mathrm{mgal}$. which cannot be explained away by the uncertainties of the measurements. It appears that the ice-sheet must have been subject to a much greater loading in the past than is effective to-day, and that the Antarctic land mass is, like Scandinavia, tending to rise. It would be most interesting to make a careful series of elevation measurements, but the technical difficulties of such observations from a continent fringed with ice are considerable.

A single American seismic result at the South Pole differed from the several that Pratt obtained in the vicinity of the pole, and this was explained by the inherent difficulty of interpreting an isolated record taken under the difficult conditions pertaining to ice-sheets. Pratt had gained a great deal of experience by the time the pole was reached, and the polar observation was a continuation of a whole series of 
reflexions on the profile hundreds of miles long, so that, apart from the fact that several independent results were obtained, Pratt's value must be accepted rather than the much deeper American figure.

A short refraction line at the South Ice station, 300 miles inland from the main Shackleton base, showed that the velocity in the 80-90 metre thick surface layer varied from 0.5 to $3.96 \mathrm{~km}$./sec., in agreement with observations in other parts of the world. An interesting point emerged from the refraction results. The line ran over undulating snow, but there was no sign on the record of the surface variations in height. It must be assumed, therefore, that the troughs of the undulations consist of lower. velocity material than do the humps. Some shots fired on the ice-shelf yielded reflexions from the sea bed, but not from the bottom of the ice. This is a familiar experience with Antarctica geophysicists, but Pratt has pointed out that a unique solution of ice thickness can be obtained from the travel time of waves reflected from the sea-bed.

Dr. Lister's simple method of following the accumulation of snow by laying down strings at fortnightly intervals and afterwards checking their profile by digging was supplemented by counting the years indicated in the stratification caused by seasonal changes in climate. Pits and drilled cores at South Ice enabled Lister to look back to the year 1895, and across the continent twenty bore-holes reached back twenty years and sixty more were deep enough to include the deposition of the past five years. Along the central portion of the traverse followed by the Trans-Antarctic Expedition the deposition-rate was found to be fairly constant at 8-9 cm. water equivalent a year. This is rather higher than the $6 \mathrm{~cm}$. found by the American observers at their South Pole Base, but may be accounted for by the fact that much of the expedition's route followed a trough in the surface topo- graphy. The accumulation increases to about $25 \mathrm{~cm}$. water equivalent at the edges of Antaretica, and Lister caiculates a deposition-rate of $13.1 \mathrm{gm} . / \mathrm{cm} .{ }^{2} /$ year as an average over the whole continent. The wastage is assessed at $10.1 \mathrm{gm} . / \mathrm{cm} .{ }^{2} /$ year mainly made up of 5.0 melting, 4.0 icebergs, 1.0 evaporation and $0 \cdot 1$ deflation. It appears then, from the present-day observations, that there is a net gain of ice, a result (ignoring any time-lag) opposite to that indicated by the negative gravity anomaly. During the discussion it became apparent that the figures for melting and for loss by breaking off of ice-floes might be changed in the light of other observations, but in any event the present material balance was one that applied to decades rather than to the thousands of years (at: least) during which changes in the ice-cap, sufficient to account for the gravity results, would be expected to take place.

Some of Lister's observations made it elear that precipitation favoured hollows rather than the crests of undulations, and that there was a migration of the crests with time. Nye raised the question of whether the presence of the undulations might affect the travel of the whole sheet, because their presence implies a big change of slope over a distance larger than the thickness of the sheet. There was clearly a mechanism here which could give local fluctuations of velocity and hence it would be very difficult to make sense of any isolated measurements of ice-sheet velocity. It is possible that the movement of the crests is only apparent, and is caused by the erosion of hard wind-blown snow at the crests of the undulations, with a simultaneous build-up of a new crest above the snow-filled troughs. Whether they are caused by aerodynamic or by hydrodynamic means, the undulations and sastrugi deserve further attention, and the results that have been collected recently should call forth a new advance on the theoretical side.
T. F. GaskelL

\section{THE NATIONAL SCIENCE FOUNDATION}

\section{REPORT FOR 1957-58}

$\mathrm{M}^{\circ}$ ORE than half the eighth annual report of the National Science Foundation for the year ended June 30, 1958*, is occupied by appendixes listing the membership and staff of the Board, its committees and advisory panels, grants for basic research, fellowship awards, publications of the Foundation and others resulting from research grants and fellowships. The latter now runs to some 1,315 items, compared with 850 in 1956-57, and is arranged according to the several divisions of the Foundation. Fellowship awards during the year totalled 1,527, amounting to about 5.6 million dollars in value. Of these, 408 were in the biological sciences, 314 in physics and astronomy, 306 in chemistry, 206 in mathematical sciences, and 193 in engineering. Of the total, 1,084 were predoctoral, 227 postdoctoral and 216 in the science faculty programme for improving the quality of science teaching. Grants for research amounted to more than 19 million dollars, and of these 1,120 grants, 605, totalling $8,881,130$ dollars, were in biological and medical sciences ; 466 grants, totalling 9,507,825 dollars, in mathematical,

* National Science Foundation. Eighth Annual Report for the Fiseall Year ended June 30,1958 . Pp. xv +246 (8 plates). (Washington, D.C. : Government Printing Office, 1959.) 1 dollar. physical and engineering sciences; and 49 grants, totalling 725,950 dollars, in social science. During the year, 190 seientists received grants, totalling 113,220 dollars, in support of travel to international scientific meetings, and the Foundation sponsored and provided partial support for thirty-four scientifie conferences and symposia.

Reviewing the support given to basic research in the sciences, in the Division of Biological and Medical Sciences, the report stresses the clue to the control of tuberculosis provided by the study of the honey guide, a wax-eating bird found primarily in Africa, from the intestinal tract of which a wax-splitting bacterium was isolated that contains a protein which inhibits the growth of the tubercle bacillus in tissue cultures. Doubts have been thrown on the basic genetic axiom regarding the individuality of genes by the discovery that the gene in corn which produces colour in the kernel can be permanently modified by bringing it into combination with a particular partner gene. Results have been obtained suggesting that some plants may operate as a wellknit group or unit having a common physiology, and it has also been found that nerve growth factors similar to the tumour factors are present in the 